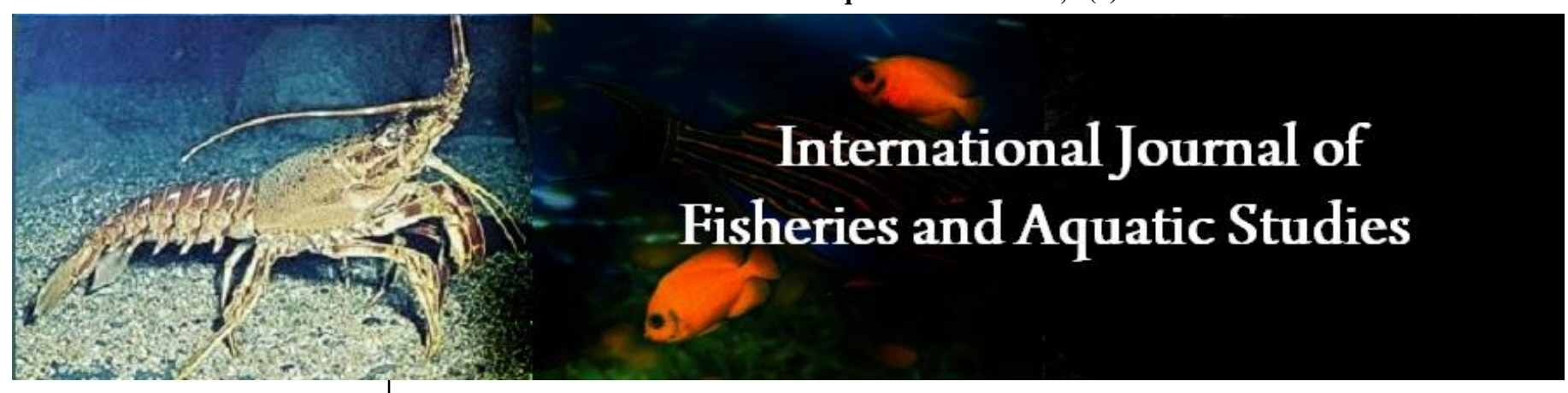

E-ISSN: 2347-5129

P-ISSN: 2394-0506

(ICV-Poland) Impact Value: 5.62

(GIF) Impact Factor: 0.549

IJFAS 2020; 8(6): 54-62

(C) 2020 IJFAS

www.fisheriesjournal.com

Received: 13-09-2020

Accepted: 16-10-2020

\section{Ezike CO}

Department of Animal/Fisheries Science \& Management, Enugu State University of Science \& Technology (ESUT) Enugu, Nigeria

Echor FO

Department of Animal/Fisheries Science \& Management, Enugu State University of Science \& Technology (ESUT) Enugu, Nigeria

\section{Agbo AN}

Department of Animal/Fisheries Science \& Management, Enugu State University of Science \& Technology (ESUT) Enugu, Nigeria
Corresponding Author:

Ezike CO

Department of Animal/Fisheries Science \& Management, Enugu State University of Science \& Technology (ESUT) Enugu, Nigeria

\section{BaP-carcinogenicity and mutagenicity, growth and food reserves of clariid catfish to the water soluble fraction (WSF) of bonny light crude oil BLCO}

\author{
Ezike CO, Echor FO and Agbo AN
}

DOI: https://doi.org/10.22271/fish.2020.v8.i6a.2447

\begin{abstract}
The toxicity and PAH of $C$. gariepinus $(0.98 \pm 0.01 \mathrm{~g}, \mathrm{n}=480)$ to $1,3,6,9,12$ and $0.0 \mathrm{ml} / \mathrm{L}$ of BLCO oil was determined and were exposed to 3 treatment sublethal concentrations $(2.40,1.20,0.60$ (corresponding to $1 / 16,1 / 8$ and $1 / 4$ of $96 \mathrm{~h} \mathrm{LC}_{50}$ ) and $0.00 \mathrm{ml} / \mathrm{L}$ of WSF of BLCO in triplicate replications of 60 fish per treatment for 10 weeks. The $96 \mathrm{~h}$ median lethal concentration of BLCO to the experimental fish fingerlings was $9.6 \mathrm{ml} / \mathrm{L}$. The mean $\sum 16 \mathrm{PAH}$ gave $6 \%$ compared to $11 \%$ that of its mean 8PAH. Mean TEQ and MEQ in 8PAH both corresponded to $11 \%$, however BaP-TEQ in BLCO ranged from 0\% in Chry to 84\% in DahA while BaP-MEQ ranged from 0\% in Chry to $30 \%$ in DahA. The respective Benzo [a] Pyrene carcinogenic and mutagenic equivalents of Clarias gariepinus to BLCO was 2 and $9 \%$. There was a significant difference $(P<0.05)$ between mean weights, length and weight gain of exposed fish and control which depreciated along concentration gradient with the lowest growths at $2.4 \mathrm{ml} / \mathrm{LWSF}$ of crude oil. Mean weight gained by fish for the control group which stood at $0.24 \mathrm{~g}$ reduced significantly by $31 \%$ to $0.07 \mathrm{~g}$ in group exposed to $2.4 \mathrm{ml} / \mathrm{L}$ WSF of BLCO. Mean FCR of the control group of fish with a value of 0.25 increased by $31 \%$ to 0.83 in exposed group to $0.24 \mathrm{ml} / \mathrm{L}$. liver glycogen and plasma glucose significantly reduced respectively by 16 and $8 \%$ to $0.64 \mathrm{mg} / \mathrm{g}$ and $0.77 \mathrm{mg} / \mathrm{L}$ at $2.4 \mathrm{ml} / \mathrm{LWSF}$ of crude oil- exposed fish which was indicative of hypoglycemia in the exposed fish.
\end{abstract}

Keywords: growth, Clarias gariepinus, water soluble fraction, crude oil, liver glycogen, plasma glucose

\section{Introduction}

The increasing incidence of oil pollution and a worldwide decline in protein ration necessitates the need for a database line of the PAH toxicity and effects of the water-soluble fractions of crude oil on the growth and food reserves of a widely distributed continental fish represented by Clarias gariepinus. The global preference for Bonny Light grade crude owing to its low sulphur content has increased production of the same in recent years in order to meet up with the high demand ${ }^{[29]}$. noted that the water-soluble fraction of crude oil which is non visible but solubilize and become bioavailable to fish and thus stay longer in water than other fractions.. In recent times, PAHs have received much attention due to their potential cause of cancer, mutagenic disorders and birth defects ${ }^{[20,27]}$. The concentrations of petroleum products toxic to aquatic organisms depend on the type and hydrocarbon constituents, as well as the species involved ${ }^{[19]}$. Estimated concentrations of petroleum toxic to fish eggs and fingerlings to be 0.5-10 mg/L Benzo (a) pyrene binds to DNA to cause cancer and is frequently used as a marker for carcinogenic disorders and may provide the basis for predicting the impact of exposures of PAH to C. gariepinus fingerlings ${ }^{[25]}$. Fishes are good indicators of pollution due to the lipophilic nature and high chemical stability of PAHs which accumulate in the fatty tissues of fish after an uptake from both inland and coastal waters [16, 15, 11]. Two broad groups exist based on their physical and biological properties including, high molecular weight (HMW) and low molecular weight (LMW) PAHs. The HMW PAHs consists of 4-6 aromatic rings and are less readily bio-degraded by indigenous microorganisms, hence can persist in the aqueous environment by bio-accumulating in aquatic organisms like fish and mussels and are more carcinogenic. The LMW PAHs consists of 2-3 aromatic rings and although less carcinogenic, also pose toxic effect to many aquatic organisms ${ }^{[4]}$. 
The concentrations of petroleum products toxic to aquatic organisms depend on the type and hydrocarbon constituents, as well as the species involved ${ }^{[19,}{ }^{18]}$. Estimated concentrations of petroleum toxic to fish eggs and fingerlings to be $0.5-10 \mathrm{mg} / \mathrm{L}$ Benzo [a] pyrene binds to DNA to cause cancer and is frequently used as a marker for carcinogenic disorders and may provide the basis for predicting the impact of exposures of PAH to $C$. gariepinus fingerlings ${ }^{[18]}$. BaPTEQ (carcinogenic equivalents and BaP- MEQ (mutagenic equivalents are measure for sum of total 8 number of particulate PAHs $\left(\sum 8 \mathrm{PAH}\right)$, having molecular weight greater than 228 gram. $\sum 8 \mathrm{PAH}$ includes benzo (a) pyrene (BaP), benz (a) anthracene (BaA), chrysene/iso-chrysene (CHR), benz (b) fluoranthene $(\mathrm{BbF})$, benzo $(\mathrm{k})$ fluoranthene $(\mathrm{BkF})$, indo (123-cd) pyrene (IP), Dibenz (a,h) anthracene (DahA) and benzo (ghi) pyrelene (BghiP) ${ }^{[24,6,7]}$. The hardy nature and possession of accessory air-breathing organs enable $C$. gariepinus to tolerate adverse aquatic conditions ${ }^{[28]}$. Nonetheless, Clarias gariepinus fingerlings are very delicate and sensitive to aquatic pollutants including crude oil and other petroleum products. This study was undertaken to determine the toxicity and levels of PAH of Nigerianpetroleum crude oil effects on the growth and food reserves of C. gariepinus fingerlings.

\section{Materials and Methods}

\subsection{Experimental fish and petroleum}

A total of one hundred and twenty (180) fingerlings of African catfish (mean weight $0.96 \pm 0.1 \mathrm{~g}$ ) were obtained from local outskirts in Enugu Nigeria and transported to Fisheries Laboratory of the Department of Animal/Fisheries Science and Management, Enugu State University of Science and Technology ESUT, Enugu Nigeria. They were held in four fiber reinforced plastic (FRP) tanks, containing $320 \mathrm{~L}$ of dechlorinated tap water. Aeration was provided to all tanks round the clock in order to maintain dissolved oxygen contents. Before the commencement of the study, the fish were acclimatized for two weeks and were fed with commercial fish diet composed of $40 \%$ crude protein. The faecal matter and other waste materials were siphoned off daily to reduce ammonia content in water. Petroleum (crude oil) was obtained from Nigerian National Petroleum Cooperation Enugu. The water soluble fraction WSF was prepared following the method of ${ }^{[33]}$, which involved $20-\mathrm{h}$ mixing of 10:1 clean water to petroleum with a rotator magnetic stirring rod, separated layers after resting for 12-hrs with separating flask before storing as stock solution in corked 50L plastic gallons. Ethical clearance from Enugu State University of Science and Technology Committee on Experimental Animal Care was obtained and followed.

\subsection{Acute toxicity test}

Toxicity of crude oil to $C$. gariepinus was carried out according to the OECD guideline for testing of chemicals No. 203 in a semi-static renewal system by using 200 L capacity glass aquaria. Thirty (60) fish per treatment were randomly exposed to 6 experimental treatments $(1,3,6,9,12$ and 0 $\mathrm{ml} / \mathrm{L}$ of water soluble fractions WSF which served as the control in triplicateto determine $96 \mathrm{~h} \mathrm{LC}_{50}$ using the probit analysis proposed by $[12,34,35]$ and polycyclic aromatic hydrocarbons $(\mathrm{PAH})$ in exposed fish ${ }^{[19]}$. The exposure was renewed each day and was analyzed using LC-MS/MS to ensure the agreement between nominal and actual concentrations of the petroleum in the aquaria. The experiment was conducted under the natural photoperiod of 12:12 light-dark cycle. The physico-chemical parameters of the test water were analyzed daily, using standard methods ${ }^{[3,}$ ${ }^{36]}$ and were recorded (dissolved oxygen $7.50 \pm 0.45 \mathrm{mg} \mathrm{L}^{-1}$, temperature $27.75 \pm 0.5{ }^{\circ} \mathrm{C}, \mathrm{pH} 7.8 \pm 0.13$ and free carbon dioxide $4.28 \pm 0.6 \mathrm{mg} \mathrm{L}^{-1}$ ). The test fish of 9 and $12 \mathrm{ml} / \mathrm{L}$ were sampled to determine $\sum 16 \mathrm{PAH}, \sum 8 \mathrm{PAH}$, TEQ and MEQ. A portion of the sample using the GC-MC was taken for extraction and analysis of PAH ${ }^{[32,22]}$.

\subsection{PAH extraction}

The method described by ${ }^{[32,17,20]}$ with slight modification for extraction and dosing of PAHs was employed. The toxic equivalent factors $\left(\mathrm{BaP}_{\mathrm{TEF}}\right)$ and mutagenic equivalent factors $\left(\mathrm{BaP}_{\mathrm{MEF}}\right)$ relating the carcinogenic mutagenic potency of individual $\mathrm{PAH}$ to $\mathrm{BaP}$ have been used [24, 31, 7]. The $\mathrm{BaP}$ carcinogenic equivalent $\left(\mathrm{BaP}_{\mathrm{TEF}}\right)$ and $\mathrm{BaP}$ mutagenic equivalent $\left(\mathrm{BaP}_{\mathrm{MEQ}}\right)$ for the individual $\mathrm{PAHs}$ was calculated: $\mathrm{BAP}_{\mathrm{TEQ}}=\sum \mathrm{C}_{1} \mathrm{X} \mathrm{BAP}_{\mathrm{TEF}} ; \mathrm{BAP}_{\mathrm{MEQ}}=\sum \mathrm{C}_{1} \mathrm{X} \mathrm{BAP}_{\mathrm{MEF}}$, where $\mathrm{Ci}=$ concentration of PAHs.

\subsection{Subacute Toxicity Test}

Three sublethal concentrations 2.40, 1.20, 0.60 (corresponding to $1 / 16,1 / 8$ and $1 / 4$ of $96 \mathrm{hC}_{50}$ ) and 0.00 $\mathrm{ml} / \mathrm{L}$ of WSF of BLCO in triplicate replications of 60 fish per treatment for 10 weeks was determined in 18 plastic vats, each containing 20 fingerlings of $C$. gariepinus. Exposure lasted for 10 weeks during which 2 juveniles were sacrificed per aquarium at fortnightly intervals to estimate carbohydrate food reserves. Feeding was conducted at $3 \%$ body weight twice daily but the fresh introduction of toxicant and syphoning of faecal matter and uneaten food was carried out weekly. Water quality parameters as determined during the acute toxicity test were conducted fortnightly following the method of ${ }^{[3]}$. The determination of plasma glucose and liver glycogen content were carried out by comparing the absorbance of anthrone portions with those of standard glucose using a colorimeter (Model 605/REV D/01-96) at 620 $\mathrm{nm}$ following the method suggested by ${ }^{[38]}$. Diet with $38 \%$ crude protein was formulated using the Pearson Square Method [23]. It was used to feed juveniles of Clarias gariepinus during the acclimation period and subacute exposure periods at $3 \%$ body weight, twice daily. Ingredient consisted of soybean meal, yellow maize, fish meal, rice bran, salt, palm oil, vitamin mix and mineral mix. These ingredients were carefully weighed out using Ohaus digital weighing balance (model Adventurer ProAV410C). This was followed by grinding of the micro-ingredients, then mixed in a mixer and pelleted with a pelleting machine. Pelleted diet was allowed to dry before packaging and usage during acclimatization and subacute exposure periods. Proximate Analyses of formulated diet was carried out according to the methods of [2] for moisture content, crude protein, ether extracts (fats), Ash content, Nitrogen free extract while water quality was estimated using the methods of ${ }^{[3]}$.

\subsection{Statistical Analysis}

Data obtained were expressed as standard mean \pm standard error of mean and analyzed using the statistical package SPSS 20.0 computer program (SPSS Inc. Chicago Illinois, USA. 


\section{Results}

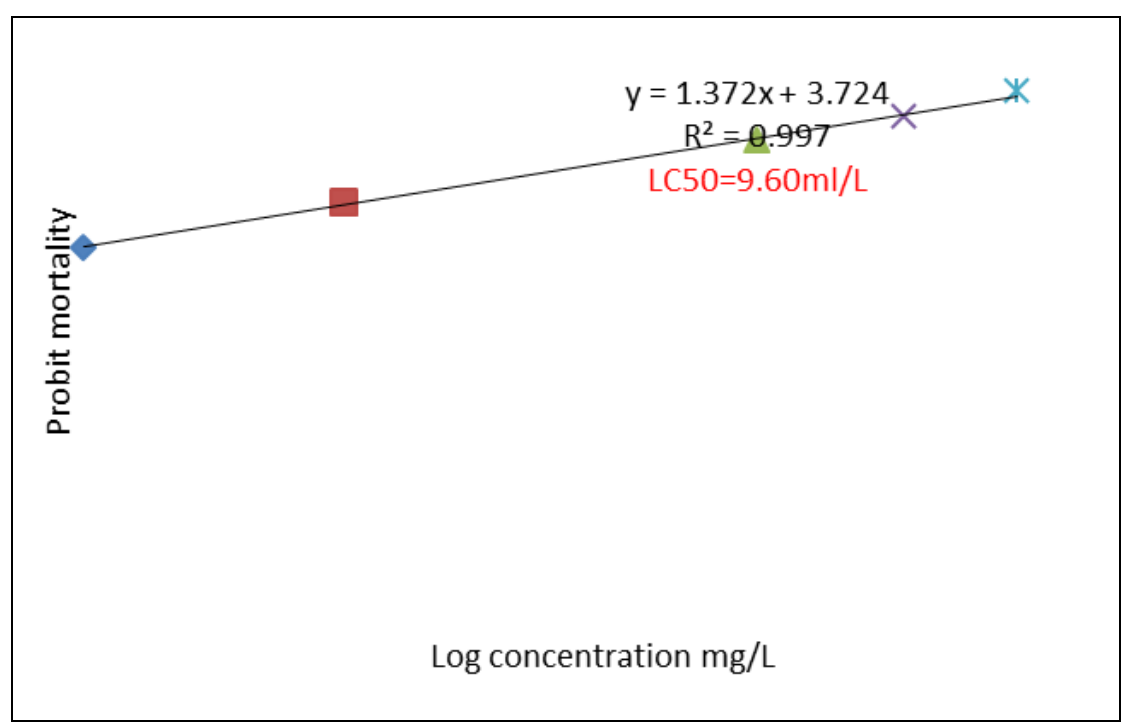

Logarithimic probit line for determination of 96-h $\mathrm{LC}_{50}$ of BLCO to $C$. gariepinus
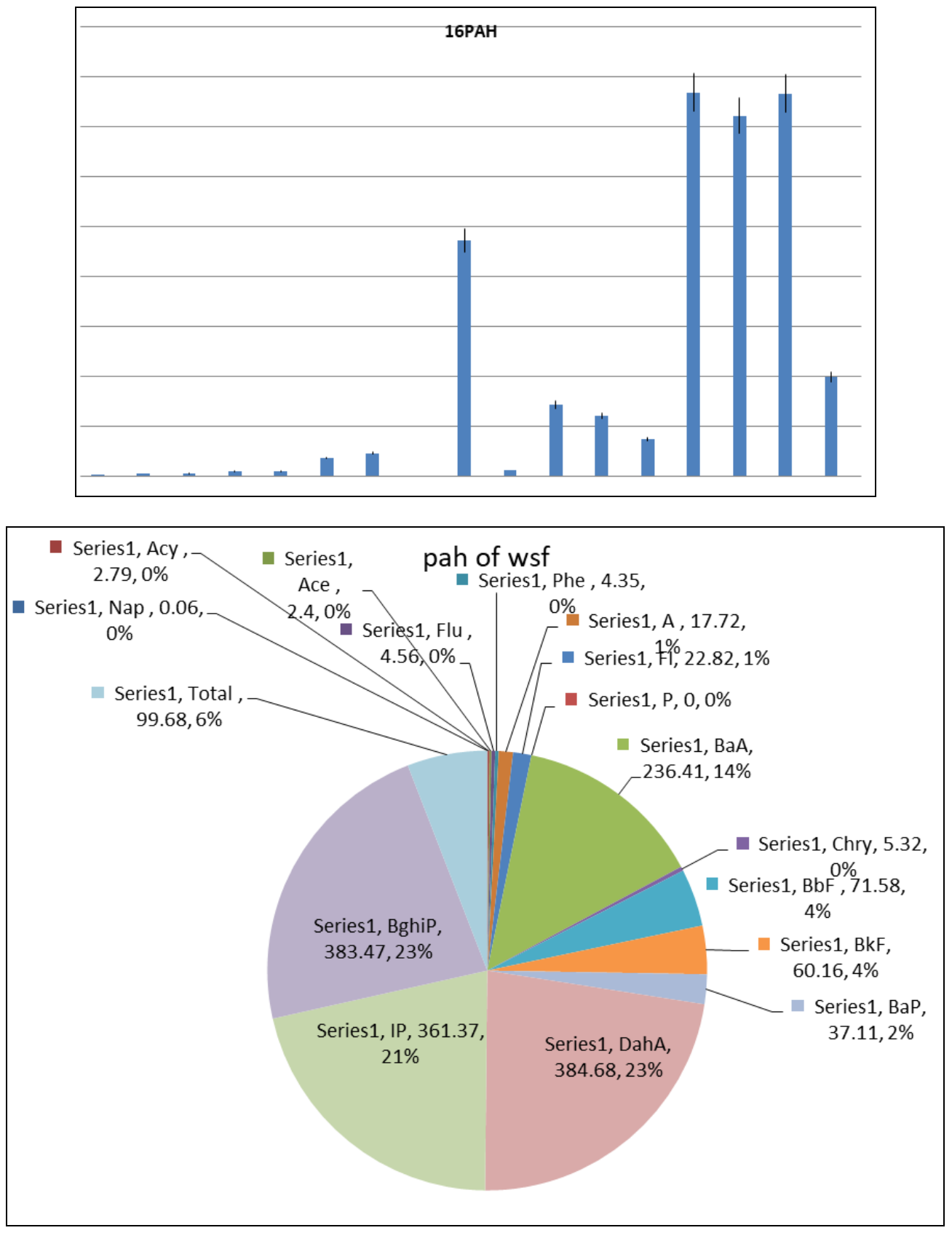

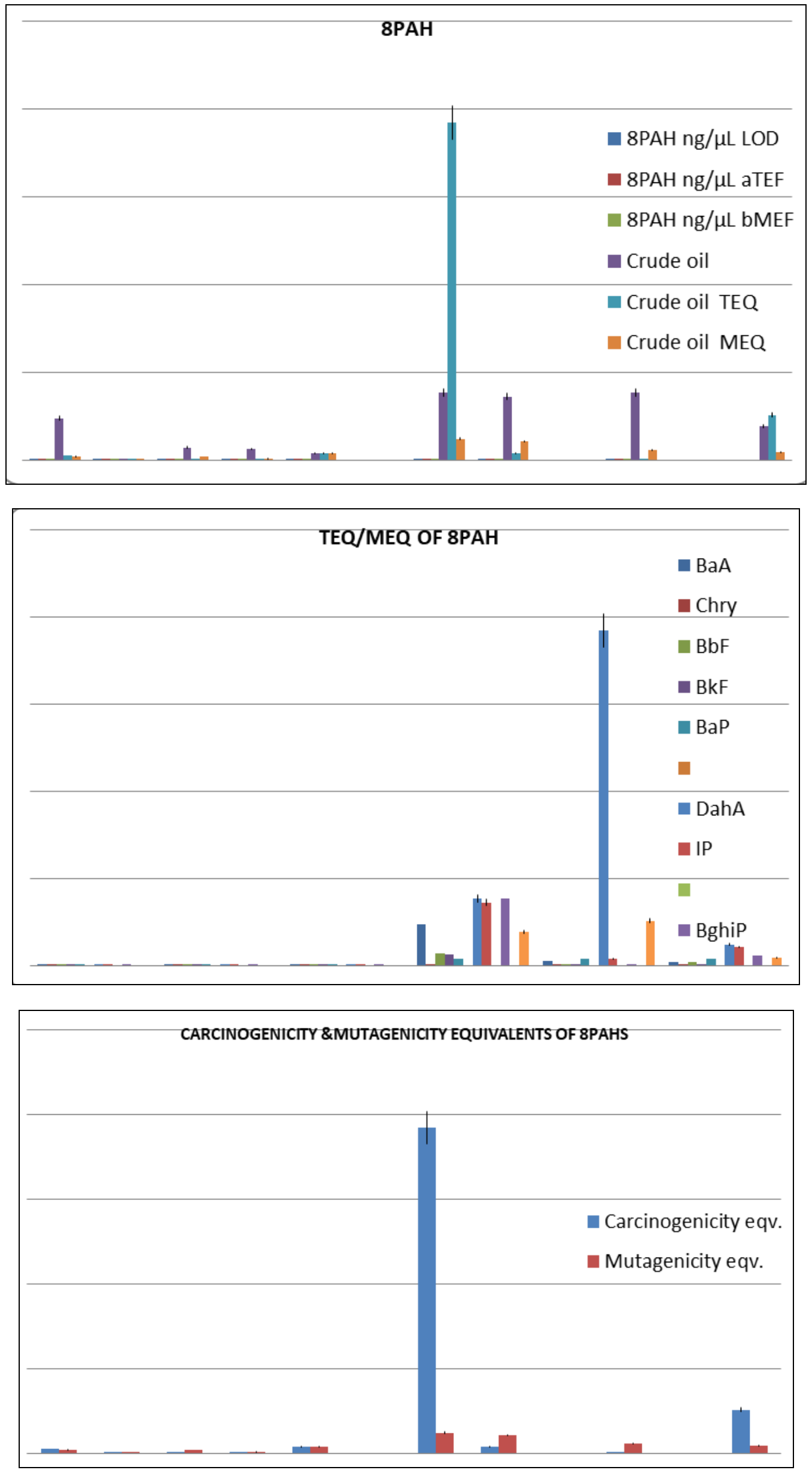

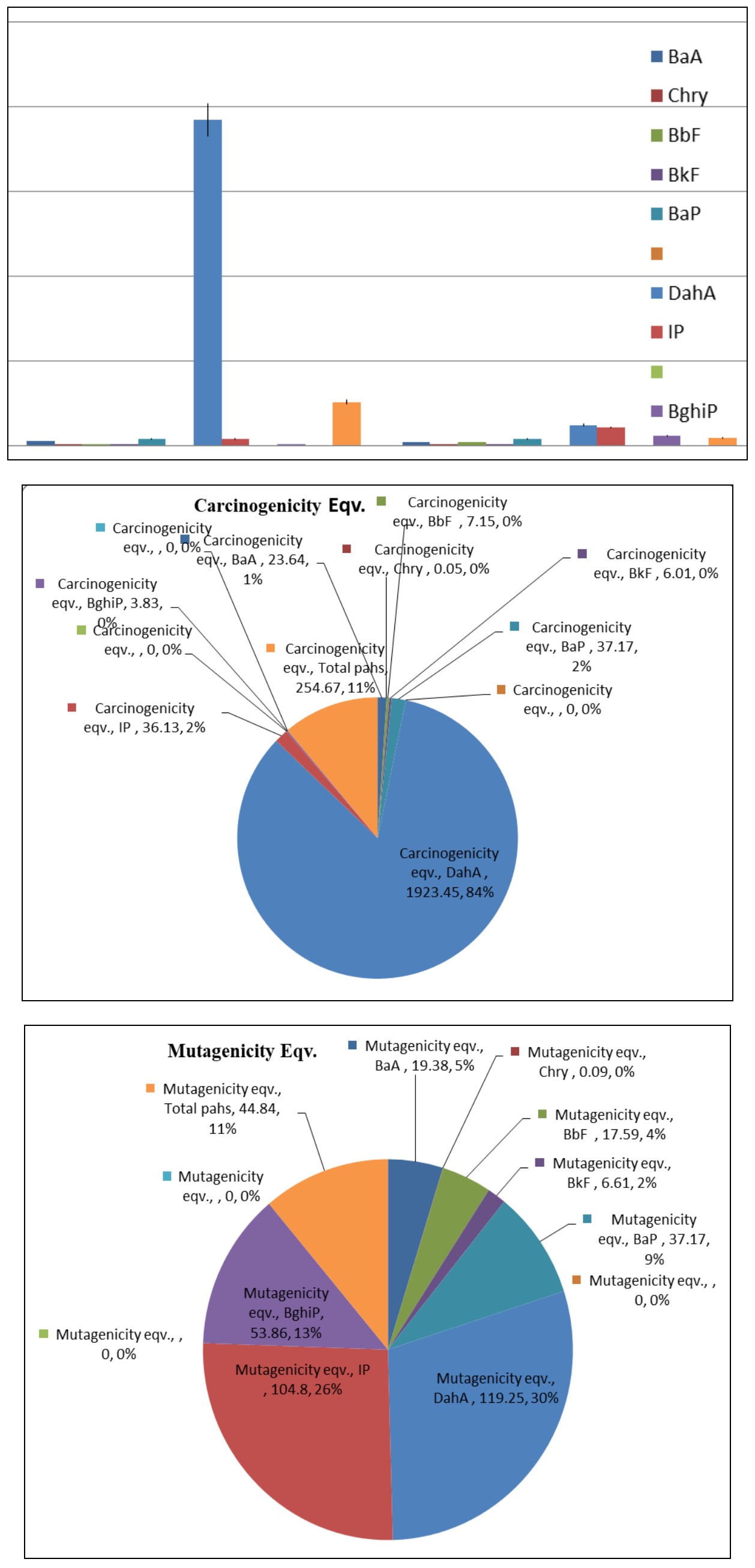


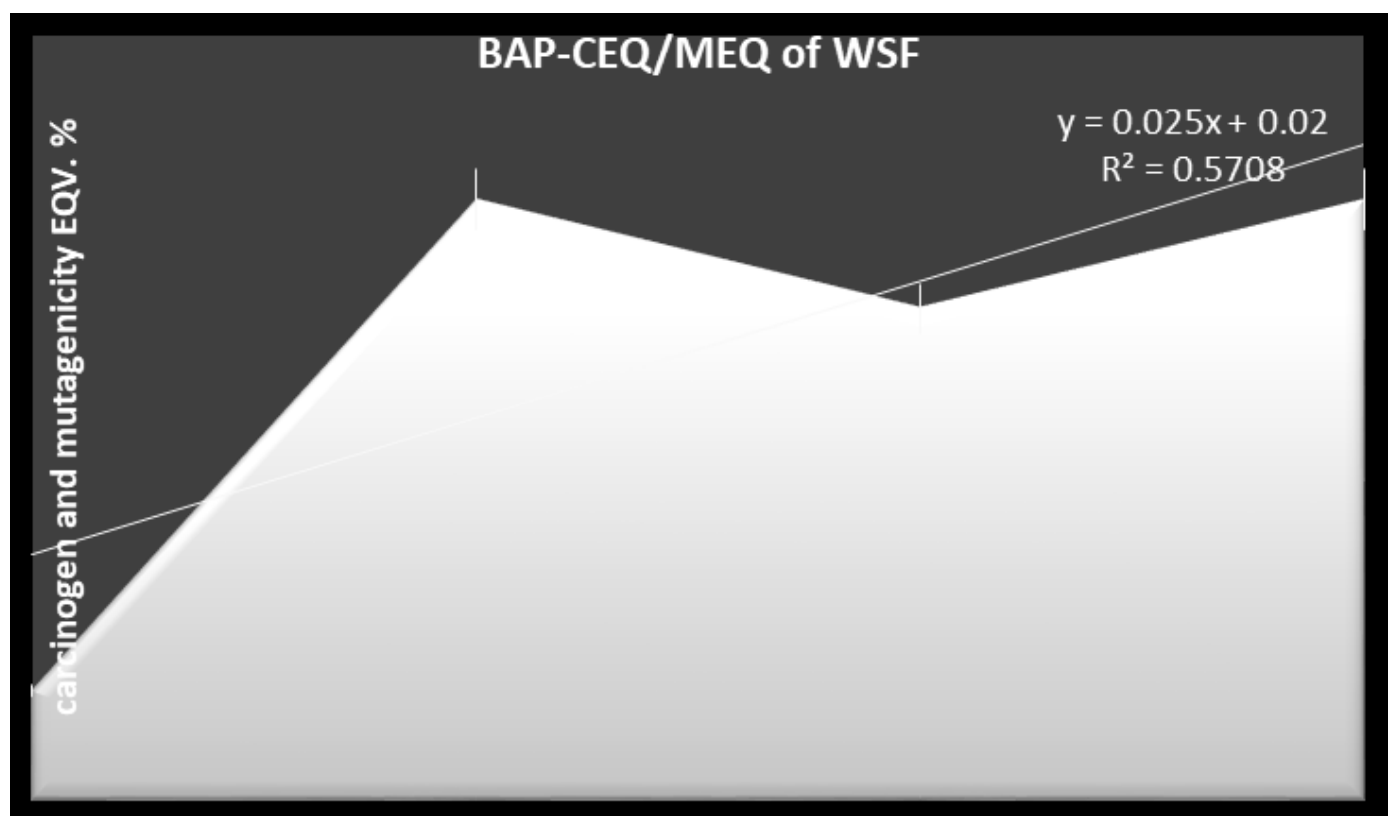

Fig 1: 16 \& 8 PAH; CEQ \& MEQ of $C$. gariepinus to BLCO

The results of the mean growth of Clarias gariepinus exposed to sublethal Concentrations of WSF of Crude oil is presented in tables and figures below

Table 1: Mean Growth and food reserves of Clarias gariepinus to WSF of crude oil

\begin{tabular}{|c|c|c|c|c|}
\hline Parameters & $\mathbf{2 . 4 0} \mathbf{m l} / \mathbf{L}$ & $\mathbf{1 . 2 0} \mathbf{~ m l} / \mathbf{L}$ & $\mathbf{0 . 6 0} \mathbf{~ m l} / \mathbf{L}$ & $\mathbf{0 . 0 0} \mathbf{~ m l} / \mathbf{L}$ \\
\hline Mean weight (g) & $0.985 \pm 0.34^{\mathrm{b}}$ & $1.03 \pm 0.40^{\mathrm{b}}$ & $1.09 \pm 0.65^{\mathrm{b}}$ & $1.27 \pm 0.17^{\mathrm{a}}$ \\
\hline Mean length (cm) & $1.247 \pm 0.38^{\mathrm{b}}$ & $1.33 \pm 0.64^{\mathrm{b}}$ & $1.38 \pm 0.68^{\mathrm{b}}$ & $1.54 \pm 0.13^{\mathrm{a}}$ \\
\hline Mean weight gain (g) & $0.07 \pm 0.003^{\mathrm{c}}$ & $0.1 \pm 0.004^{\mathrm{b}}$ & $0.13 \pm 0.003^{\mathrm{b}}$ & $0.24 \pm 0.004^{\mathrm{a}}$ \\
\hline FCR & $0.83^{\mathrm{b}}$ & $0.60^{\mathrm{c}}$ & $0.45^{\mathrm{c}}$ & $0.25^{\mathrm{d}}$ \\
\hline Liver glycogen & $0.64 \pm 0.04^{\mathrm{c}}$ & $0.76 \pm 0.05^{\mathrm{b}}$ & $0.78 \pm 0.05^{\mathrm{b}}$ & $1.18 \pm 0.02^{\mathrm{a}}$ \\
\hline Plasma glucose & $0.77 \pm 0.01^{\mathrm{d}}$ & $0.89 \pm 0.01^{\mathrm{c}}$ & $0.96 \pm 0.02^{\mathrm{b}}$ & $1.05 \pm 0.05^{\mathrm{a}}$ \\
\hline
\end{tabular}

Means on a row with the same superscript are not significantly different but means with different superscript are significantly different. Mean separation by Duncan's Multiple Range Test at 5\% level of significance ( $\mathrm{P}>0.05$ ).

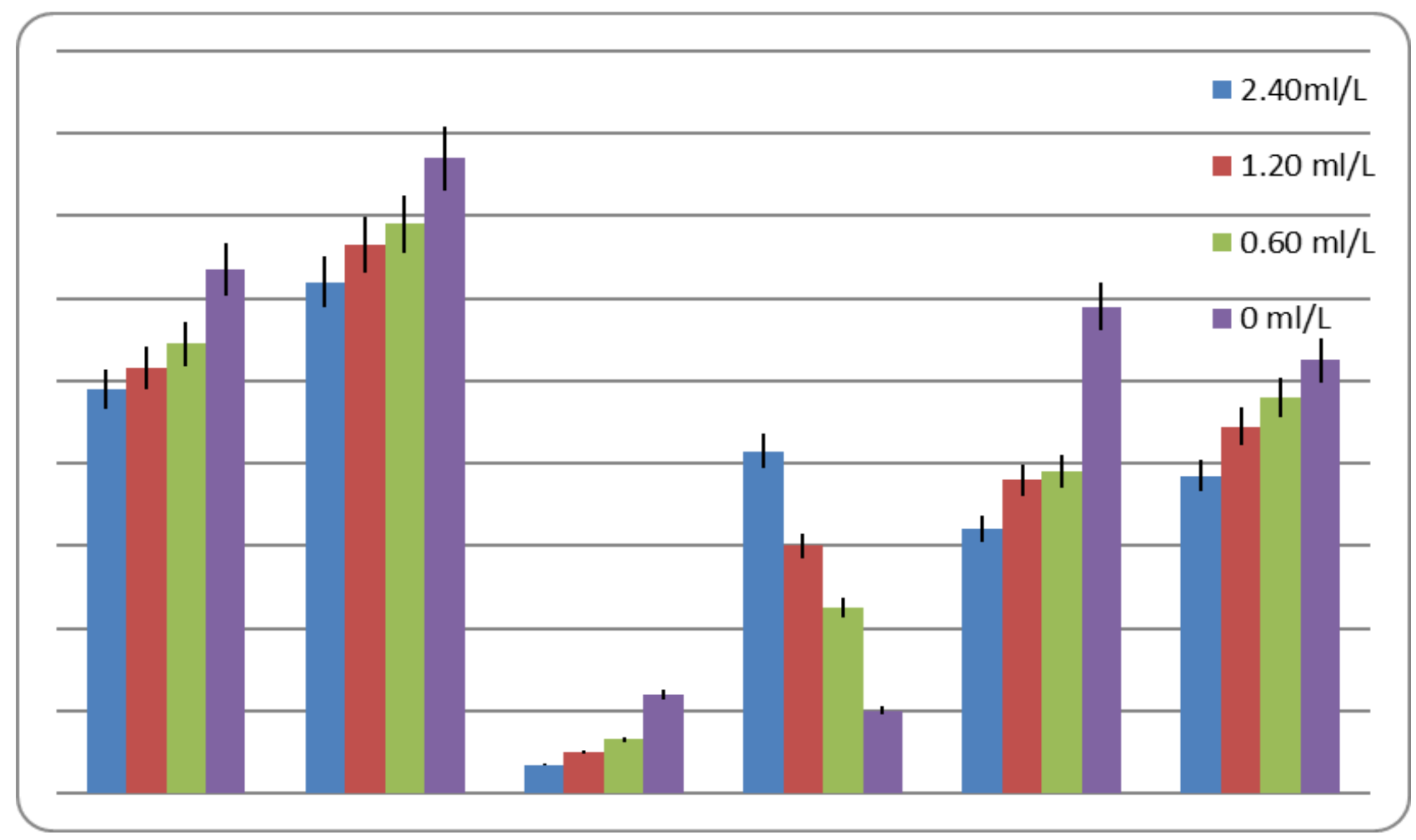



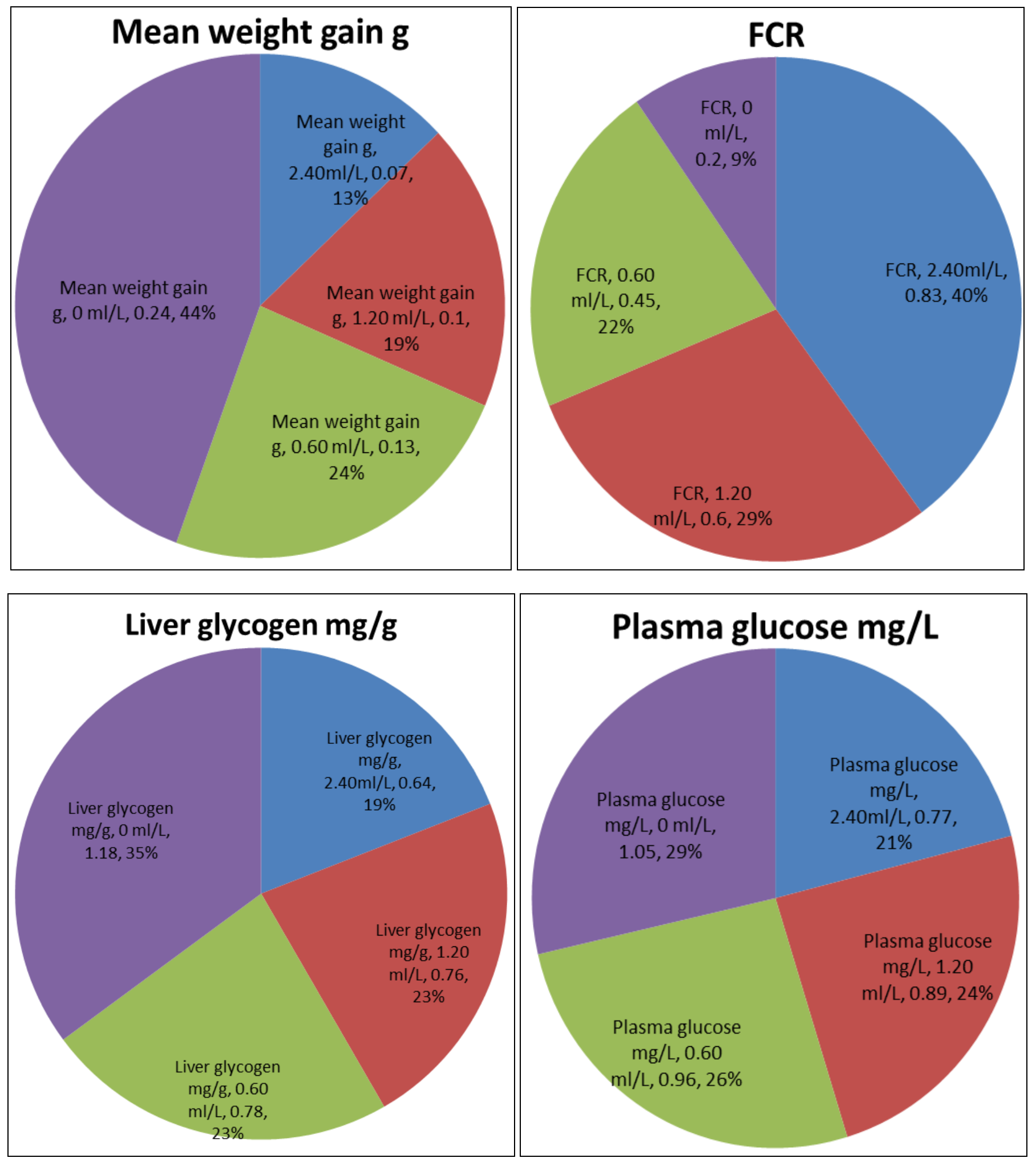

Fig 2: Growth and food reserves of $C$. gariepinus to sublethal concentrations of BLCO

\subsection{Growth of Clarias gariepinus}

There was a significant difference $(P<0.05)$ between mean weight, length and weight gain of exposed fish and control which depreciated along concentration gradient with the lowest growths at $2.4 \mathrm{ml} / \mathrm{LWSF}$ of crude oil. Mean weight gained by fish for the control group which stood at $0.24 \mathrm{~g}$ reduced significantly by $31 \%$ to $0.07 \mathrm{~g}$ in group exposed to
2.4ml/L WSF of BLCO. Mean FCR of the control group of fish with a value of 0.25 increased by $31 \%$ to 0.83 in exposed group to $0.24 \mathrm{ml} / \mathrm{L}$. liver glycogen and plasma glucose significantly reduced respectively by 16 and $8 \%$ to $0.64 \mathrm{mg} / \mathrm{g}$ and $0.77 \mathrm{mg} / \mathrm{L}$ at $2.4 \mathrm{ml} / \mathrm{LWSF}$ of crude oil- exposed fish which was indicative of hypoglycemic alterations in the exposed fish. 
Table 2: Gross \& Proximate analysis of Diet

\begin{tabular}{|c|c|}
\hline \multicolumn{2}{|c|}{ Ingredients \% of crude protein inclusion } \\
\hline Yellow maize (10\%) & 9.28 \\
\hline Soybean meal (40\%) & 54.85 \\
\hline Fish meal (64\%) & 16.75 \\
\hline Rice bran (8\%) & 15.37 \\
\hline Micronutrient inclusion \\
\hline Salt & 0.25 \\
\hline Palm oil & 0.5 \\
\hline Vitamin mix & 0.6 \\
\hline Mineral mix & 2.4 \\
\hline Total & 100 \\
\hline Proximate Analysis of Formulated Diet \\
\hline Crude protein & 37.8 \\
\hline Ether extracts & 0.57 \\
\hline Ash & 5.69 \\
\hline Moisture & 8.59 \\
\hline Nitrogen-free extract & 45.55 \\
\hline Crude fibre & 1.8 \\
\hline Total & 100 \\
\hline
\end{tabular}

\section{Discussion}

The WSF of BLCO has shown the ability to cause more changes in the genetic makeup and may damage the genome materials than its ability to cause cancer in exposed fish ${ }^{[14]}$. The impact of petroleum water soluble fraction previously under-reported has in recent times posed critical health concerns to aquatic biota, especially fish ${ }^{[13,30]}$. The foregoing gave an indication that petroleum products with high molar mass and greater mean $\Sigma 8 \mathrm{PAH}$ were more carcinogenic and mutagenic compared to lighter petroleum with lower mean $\sum$ 8PAH. Recent approaches have centered to identify and quantify PAHs in water, soil and air environment, their emission sources through various methods in order to evaluate their carcinogenic and mutagenic effects to human health ${ }^{[12,}$ 26, 5]. The approaches distinguish anthropogenic multiple releases chiefly from petroleum and other sources ${ }^{[25,14]}$. BaP is widely accepted as the indicator for measurement of carcinogenicity, thus BaP-equivalent toxicity for other carcinogenic PAHs has been recommended [39, 4] and evaluated for cancer risk assessment [24, 7, 27, 37]. The result showed that BLCO contained greater percentage mean of 8PAH than 16PAH and was less carcinogenic than mutagenic to exposed group of $C$. gariepinus. There is greater need for further investigation of the biochemistry and physiology on the mutagenicity to both fish, animals and humans alike that consume them given high mutagenicity responses of the experimental fish to BLCO in the present research. The lowered mean weight gain of exposed fish to WSF of BLCO compared to the control group agreed with previous reports of $[21,1]$ when they exposed same species to petroleum and ultraviolet radiation. Toxicant effect hindered food intake and resulted to increased rate of food conversion which possibly led to poor growth among exposed groups of fish. Some authors noted that petroleum impairment of carbohydrate metabolism in test fish was due to allocation of greater energy to the breakdown of aromatic hydrocarbon and excretion of the same which lead to reduction in growth among the exposed fish ${ }^{[10,9]}$. Thus water-soluble fractions of crude oil stimulated hydrocarbon metabolism at the expense of tissue growth which might have lead to poor growth among exposed group than control fish $[10,8]$. The present research is suggestive that the WSF of BLCO elicited hypoglycemic condition in test fish.

\section{Conclusion}

The respective Benzo [a] Pyrene carcinogenic and mutagenic equivalents of Clarias gariepinus to BLCO was 2 and $9 \%$. Mean weight gained by fish for the control group which stood at $0.24 \mathrm{~g}$ reduced by $31 \%$ while Mean FCR of the control group of fish increased by the same rate to the exposed group at the highest concentration. liver glycogen and plasma glucose significantly reduced respectively by 16 and $8 \%$ from control to the highest exposed group and thus elicited hypoglycemic alterations in the exposed fish.

\section{References}

1. Alaa GMO, Ahmed SAH. Hematotoxic and Genotoxic Potentials of Ultraviolet Radiation on the African Catfish Clarias gariepinus (Burchell, 1822). Journal of Fisheries International 2010;5(3):44-53.

2. AOAC. Official method of analysis, Association of Official Analytical Chemists.14th edition; S. Williams (ed). Arlington, V.A. USA. 1990, 1102.

3. APHA. American Public Health Association, American Water works Association and Water Environmental Federation). Standard Methods of Examination of water and Wastewater. 21st ed. APHA Washington DC, 2005, 20001-23710.

4. Brown J, Peake B. Sources of heavy metals and polycyclic aromatic hydrocarbons in urban storm water runoff. Sci. Total Environ 2006;359:145-155.

5. Changsheng Q, Bing L, Haisui W. Multi-pathway assessment of human health risk posed polycyclic aromatic hydrocacbon, Environ Geochem Health 2015;37:1-15.

6. Choi H, Harrison R, Komulainen H, Delgado SJ. Polycyclic aromatic hydrocarbons.WHO Guidelines for Indoor Air Quality: Selected Pollutants. Geneva: World Health Organization 2010. Retrieved 2014-12-12.

7. Durant J, Lafleur A, Busby W et al. Human cell mutagenicity of oxygenated, nitrated and unsubstituted polycyclic aromatic hydrocarbons associated with urban aerosols\|, Mutation Research/Genetic Toxicology and Environmental Mutagenesis 1996;371:123-157.

8. Emeline PG, Richardo VR, Caue BM, Luis AR, Lufs AS, Keber CM.. Growth and histopathological effects of chronic exposition of marine Pejerrey fish Odontesthes argentinensis larvae to a petroleum water-soluble fraction. AMBIO -Springer. 2012;41(5):456-466.

9. Esenowo IK, Ugwumba OA. Growth responses of catfish Clarias gariepinus exposed to a water-soluble fraction of detergent and diesel oil. Environmental Research Journal 2010;4(4):298- 301.

10. Ezike C, Ufodike EBC. Plasma glucose and liver glycogen of the African catfish Clarias gariepinus exposed to petrol. Journal of Fisheries International 2008;3(2):46-48.

11. Ezike CO, Echor FO, Malachy NOA, Vera LM. Butrylacetycholinesterase activites in liver and plasma, liver glycogen and plasma glucose content, haematology and behaviour of Clariid Catfish Clarias gariepinus to Dichlorvos International Journal of Advanced Fisheries and Aquatic Sciences 2017;3(1):90-105. Doi: https://doi.org/10.23953/cloud/ijafas.332. crossref:23953/cloud.ijafas.332

12. Finney DJ. Probit Analysis Canbrige University Press London 1971, 23-125.

13. Hylland K. Polycyclic aromatic hydrocarbon (PAH) 
ecotoxicology in marine systems. Journal of Toxicology and Environmental Health, 2006A; 69(1-2):109-123.

14. Isioma $\mathrm{T}$, Ozekeke $\mathrm{O}$, Lawrence E. Human health risk assessment of polycyclic aromatic hydrocarbons (PAHs) in smoked fish species from markets in Southern Nigeria. Toxicology Reports 2017;4:56-61.

15. Lawal AT. Polycyclic aromatic hydrocarbons, a review. Environmental Science 2017;3:1339841. https://doi.org/10.1080/23311843.2017.1339841.

16. Lee RF. Metabolism of petroleum hydrocarbons in marine sediments. In: Sources, effects and sinks of hydrocarbons in aquatic environment. American Institute Biological Sciences, 1976, 333-344.

17. Li N, Leu HK. Solid phase extraction of polycyclic hydrocarbons in surface water. J. Chromatogr. A 2001;921:255-263.

18. Li ZH, Velisek J, Zlabek V. Chronic toxicity of verapamil on juvenile rainbow trout (Oncorhynchus mykiss): effects on mor-phological indices, hematological parameters and antioxidant responses. J. Hazard Mat 2001; $185: 870-880$.

19. Lonning S. The effects of crude oil and oil products on marine fish larvae. Astate 1977;10:37-47.

20. Martinez E, Gros M, Lacorte S, Barcel D. Simplified procedures for the analysis of polycyclic aromatic hydrocarbons in water sediments and mussels. J. Chromatogr A, 2004;1047:18-188.

21. Moles A, Rice SD. Effects of Crude oil and Naphthalene on growth, caloric content and fat content of pink salmon juveniles in sea water. Transactions of the American Fisheries Society 1983;112:205-211.

22. Neff JM. Polycyclic aromatic hydrocarbons. in: Rand G.M. and Petrocelli S.R. (eds.). Fundamentals of aquatic toxicology. Hemisphere Publ. Corp. New York 1985, 416-454.

23. New M. Feed and feeding of fish and shrimp. A manual on the preparation and presentation of compounded feeds for fish and shrimp in Aquaculture. Aquaculture Development and Co-ordination Programme. Report No 1987;87(26):275.

24. Nisbet IC, LaGoy PK. Toxic equivalency factors (TEFs) for polycyclic aromatic hydrocarbons (PAHs). Regul. Toxicol. Pharmacol 1992;16:290-300.

25. Payne JF, Penrose WR. Induction of akyl hydrocarbon (benzo (a) Pyrene) hydroxylase in fish by petroleum. Bull Environ. Contam. Toxicol 1975;14:112-226.

26. Peng C, Chen W, Liao X, Wang M, Zhiyun Q, Jiao W, Yang B. Polycyclic aromatic hydrocarbons in urban soils of Bejing: Status, Sources, distribution and potential risk. Environmental Pollution 2011;159:802-808.

27. Ramesh A, Archibong A, Hood DB, Guo Z, Loganathan BG. Global environmental distribution and human health effects of polycyclic aromatic hydrocarbons. Global Contamination Trends of Persistent Organic Chemicals. Boca Raton FL: CRC Press 2011, 97-126.

28. Reed WJ, Burchard Hopson AJ, Jonathan J, Ibraham Y. Fish and Fisheries of Northern Nigeria. Govt. Press, London, 1967, 226.

29. Richardo VR, Weber CM, Emeline PG, Caue BM, Luis AR, Luis AS. Deleterous effects of water soluble fraction of petroleum diesel and gasoline on marine pejerry Odontesthes argentinensis larvae. Science of the total environment 2010;408:2054-2059.

30. Roubal WT, Collier TK, Malins DC. Accumulation and metabolism of carbon - 14 labelled benzene, naphthalene and Anthracene by young cohosalmon (Onchorynchus Kisutch) Arch. Environ. Contam. Toxicol 1977;5:515529.

31. So - Young L, Lee- Yeon I, Han-Seun S. Evaluation and chemical analysis method and determination of polycyclic aromatic hydrocarbon content in seafood and diary products. Toxicology Reports 2015;31(3):265-271.

32. Takatsuki S, Susuki S, Sato N, Ushizawa I. Association of Official Analytica Chemists. Toxicology, 1985;79(2):221-271.

33. United Nations Environmental Programme (UNEP), (1989). Comparative toxicity of water accommodated fraction of oil and oil dispersants to marine organisms. United Nations Environmental programme. Reference Methods for Marine Pollution Studies 1989;43:27.

34. United States Environmental Protection Agency (USEPA), (1997). Washington, DC, EPA/600/P-95/002F a-c Exposure Factors Handbook (1997 Final Report)| Risk Assessment,

https://cfpub.epa.gov/ncea/risk/recordisplay.cfm?deid=12 464.

35. USEPA The United States Environmental Protection Agency. A Review of the Reference Dose and Reference Concentration Processes. Risk Assessment Report No 2, Washington DC, 2002, 630.

36. USEPA The United States Environmental Protection Agency. Comparative Toxicity of Louisiana Sweet Crude Oil (LSC) and Chemically Dispersed LSC 2012. (Online: http://www.epa.gov/record/2012/LSC/gulfofmexicico.cf m?Direntry/dc228203).

37. Vo Thi LH, Nguyen Thi TH, Minora Y. Human health hazard of polycyclic aromatic hydrocarbon in road dust in Ha Noi metropolis. Journal of Science and Technology 2016;54(24):27-34.

38. Wedemeyer GA, Yasutake WY. Clinical Method for the Assessment of the Effects of Environmental Stress on Fish Health. Technical Washington DC, 1977;89:18.

39. World Health organization (WHO), WHO Guidelines for indoor air quality: selected 2010. pollutants, www.euro.who.int/data/assets/pdffile/0009/128169/e945 35 . 